\title{
Konsep Pengelolaan Koperasi Pesantren untuk Kesejahteraan Ekonomi Masyarakat: Telaah Surah Al-Hasyr Ayat 7
}

\author{
${ }^{1}$ Ahmad Lutfi Rijalul Fikri, ${ }^{2}$ Muaidy Yasin, ${ }^{3}$ Akhmad Jupri \\ ${ }^{1,2,3}$ Program Studi Magister Ilmu Ekonomi Universitas Mataram, Indonesia \\ ${ }^{1}$ Email korenpondensi: luthfi2311@gmail.com
}

Recieved 09-06-2018 | Revised 05-07-2018 | Accepted 16-07-2018

\begin{abstract}
The Qur'an becomes the basis of the whole teachings of Islam is not just about the collection of rules and prohibitions, but provide assurance for the realization of economic prosperity of the community. In this article, the author intends to reveal the clarity of the concept of pesantren co-operative management for the economic welfare of the community in the perspective of the letter al-Hashr verse 7. This study uses qualitative-deductive research methods. The result of this study concluded that the economic welfare is not solely mere problem of mere economic distribution but also concerning nonmaterial elements and other areas. Therefore, to achieve growth and development materially and spiritually, Islamic Economics has characteristics in its growth, which is all-round, balanced, realistic, fair, responsible, sufficient and focused on human beings in accordance with their right as khalifah on earth. These characteristics indicate that the goal of growth and economic development in Islam is the opportunity of all members of any community of race, religion and character - to gain prosperity, so that everyone can experience the blessings and grace of Allah.
\end{abstract}

Keywords: Cooperative Management, Economic growth, Economic development, Economic Welfare

\section{Abstrak}

Al-Quran menjadi landasan dari keseluruhan ajaran Islam tidak sekedar berisi tentang kumpulan peraturan dan larangan, tetapi memberikan jaminan untuk terwujudnya kesejahteraan ekonomi masyarakat. Pada artikel ini, penulis bermaksud mengungkap kejelasan konsep pengelolaan koperasi pesantren untuk kesejahteraan ekonomi masyarakat dalam perpektif surat al-Hasyr ayat 7. Penelitian ini menggunakan metode penelitian kualitatif-deduktif. Hasil kajian menyimpulkan bahwa kesejahteraan ekonomi bukan semata-mata hanya permasalahan distribusi ekonomi secara materi semata-mata tetapi juga menyangkut unsur non materi dan bidang-bidang yang lainnya. Oleh karena itu, untuk mencapai pertumbuhan dan perkembangan secara material dan spiritual tersebut, Ekonomi Islam mempunyai karakteristik dalam pertumbuhannya, yaitu serba meliputi, berimbang, realistis, berkeadilan, tanggungjawab, mencukupi dan berfokus pada manusia sesuai dengan haknya sebagai khalifah di muka bumi. Karakteristik tersebut menunjukkan bahwa tujuan pertumbuhan dan pembangunan ekonomi dalam Islam adalah adanya kesempatan semua anggota masyarakat apapun ras, agama dan karakternya - untuk mendapatkan kesejahteraan, sehingga semua orang dapat merasakan nikmat dan karunia Allah SWT.

Kata kunci: Pengelolaan Koperasi, Pertumbuhan Ekonomi, Perkembangan Ekonomi, Kesejahteraan Ekonomi.

Saran sitasi: Fikri, A., Yasin, M., \& Jupri, A. (2018). Konsep Pengelolaan Koperasi Pesantren untuk Kesejahteraan Ekonomi Masyarakat: Telaah Surah Al-Hasyr Ayat 7. Jurnal Ilmiah Ekonomi Islam, 4(2), 91-102. doi:http://dx.doi.org/10.29040/jiei.v4i2.249

DOI: http://dx.doi.org/10.29040/jiei.v4i2.249 


\section{Pendahuluan}

Koperasi sebagai wadah ekonomi kerakyatan memiliki nilai instrumental yang paling penting yaitu nilai instrumental kerja sama ekonomi. Hal ini terlihat jelas dalam pasal 33 UUD 1945 yang mengatakan bahwa "perekonomian disusun sebagai usaha bersama atas asas kekeluargaan". Ini menunjukkan bahwa perekonomian indonesia harus disusun sebagai usaha bersama (ta'awwun) berdasarkan atas asas kekeluargaan dan atau kerja sama. Mengenai betapa pentingnya masalah kerjasama ini Ibnu Khaldun mengatakan bahwa: "kebutuhan manusia sangat banyak, untuk itu diperlukan usaha yang banyak juga... adalah di luar kemampuan manusia untuk melakukan semua itu ataupun sebagiannya, kalau hanya sendirian saja. Jelaslah bahwa ia tidak dapat berbuat banyak tanpa bergabung dengan beberapa tenaga lain dari sesama manusia, jika ia hendak memperoleh makanan bagi dirinya dan sesamanya. Dengan bergotong royong (ta'awun) maka kebutuhan manusia kendati beberapa kali lebih banyak dari jumlah mereka dapat dipenuhi (Ibnu Khaldun, 2011).

Kerja sama ini merupakan pengejawantahan dari larangan Allah swt, untuk tidak beredarnya harta diantara orang kaya saja, (QS. Al-Hasyr [59]:7) karena beredarnya harta dikalangan orang-orang tertentu akan mendatangkan ketidak-adilan dan kedzaliman bagi masyarakat luas. Larangan ini dipertegas oleh Ali Syariati mengatakan bahwa dalam Al-Quran, dua pertiga ayat-ayatnya berisi tentang keharusan menegakkan keadilan/pemberdayaan ekonomi, dan membenci kezhaliman dengan ungkapan kata zhulm, Itsm, dhalal, dll (Madjid, 1984).

Dari penjelasan di atas, terlihat betapa pentingnya dan strategisnya peran kerja sama dalam kehidupan ekonomi bagi terpenuhinya kebutuhan dan terciptanya kesejahteraan bagi seluruh umat manusia. Bahkan mengingat pentingnya peran kerja sama tersebut dalam kehidupan ekonomi, terutama kehidupan ekonomi suatu negara, menurut Swasono, (2007) "tanpa adanya kemauan untuk memperhitungkan unsur dan mekanisme kerja sama, dan tanpa adanya kemauan bekerja sama (willingnes to cooperate), teori pertumbuhan ekonomi akan cacat pada tataran empirik". Kalau kita menilik kembali prinsip koperasi sebagai wadah untuk membantu kesejahteraan para anggota dalam bentuk gotong royong/kerjasama, yang mana hal ini sesuai dengan prinsip syariah yaitu ta'awanu ala al-birri dan bersifat kolektif dalam membangun kemandirian hidup.

Koperasi Pondok Pesantren memiliki potensi yang besar sebagai sebuah lembaga untuk mengembangkan dan meningkatkan kesejahteraan ekonomi masyarakat. Dewasa ini, keistimewaan dan keunikan yang dimiliki pesantren, dianggap belum mampu menjawab kebutuhan masyarakat yang semakin kompleks seiring dengan kemajuan zaman dalam era yang modern. Hal tersebut dikarenakan sejak berdirinya, pesantren memiliki potensi yang strategis di tengah masyarakat. Walaupun kebanyakan pesantren lebih memposisikan dirinya sebagai lembaga pendidikan dan keagamaan (tafaqquh fi al-din), namun beberapa pesantren mencoba melakukan reposisi sebagai bagian dari upaya merespon dinamika sosial. Paradigma ini tumbuh karena pesantren memandang bahwa kehidupan dunia akhirat harus berjalan seimbang dan menyatu. Meninggalkan salah satu diantara keduanya sama dengan melanggar sunnatullah. Dari paradigma inilah kemudian lahir program sebagai upaya untuk menggapai kesejahteraan dunia dan akhirat. Salah satunya dengan mendirikan lembaga ekonomi yang berada di pesantren, semisal koperasi dan yang lainnya. Mengingat aktivitas ekonomi merupakan salah satu sarana untuk hidup sejahtera di dunia, diharapkan akan mampu menjadi pendorong atau sebagai fasilitas untuk mencapai kesejahteraan di akhirat maka aktivitas ekonomi ini adalah anjuran agama bagi setiap manusia, hal inilah yang mendapatkan respon positif oleh pesantren. Tulisan ini mencoba menjelaskan bagaimana konsep surah AlHasyr dalam pengelolaan koperasi pesantren untuk kesejahteraan untuk kesejahteraan ekonomi masyarakat. 


\section{Metode Penelitian}

Penelitian ini menggunakan metode penelitian kualitatif-deduktif, Penelitian kualitatif merupakan penelitian yang lebih mengutamakan pada masalah proses dan makna/persepsi, di mana penelitian ini diharapkan dapat mengungkap berbagai informasi kualitatif dengan deskripsi-analisis yang teliti dan penuh makna, yang juga tidak menolak informasi kuantitatif dalam bentuk angka maupun jumlah. Pada tiap-tiap obyek akan dilihat kecenderungan, pola pikir, ketidakteraturan, serta tampilan perilaku dan integrasinya sebagaimana dalam studi kasus genetik (Muhadjir, 1996).

Sementara cara berpikir deduktif dikenal sebagai cara berpikir dimana ditarik suatu kesimpulan yang bersifat umum dari berbagai kasus yang bersifat individual. Berpikir secara induktif dimulai dengan mengemukakan pernyataan-pernyataan yang mempunyai ruang lingkup yang khas dan terbatas dalam menyusun argumentasi yang diakhiri dengan pernyataan yang bersifat umum (Izhar, 2006).

Penelitian kualitatif-deduktif berusaha untuk mengangkat secara ideografis berbagai fenomena dan realitas sosial. Pembangunan dan pengembangan teori sosial dapat dibentuk dari empirki melalui berbagai fenomena atau kasus yang diteliti. Dengan demikian teori yang dihasilkan mendapatkan pijakan yang kuat pada realitas, bersifat kontekstual dan historis (Gumilar, 2005).

\section{Hasil dan Pembahasan}

\subsection{Distribusi Ekonomi dalam Surat Al-Hasyr}

\section{Ayat 7}

Dalam mushhaf al-Hasyr adalah surat ke-59. Sedangkan berdasarkan kronologis nuzuul-nya ia turun setelah surat al-Bayyinah (98) sebelum surat an-Nuur (24).

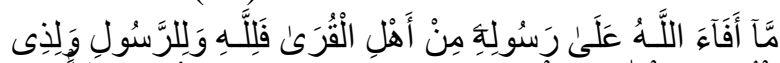

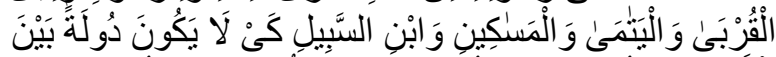

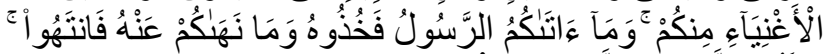

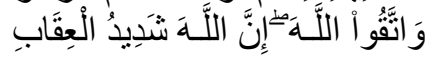

Artinya: "Apa saja harta rampasan (fai') yang diberikan Allah kepada RasulNya (dari harta benda) yang berasal dari penduduk kotakota Maka adalah untuk Allah, untuk rasul, kaum kerabat, anak-anak yatim, orang-orang miskin dan orang-orang yang dalam perjalanan, supaya harta itu jangan beredar di antara orang-orang Kaya saja di antara kamu. apa yang diberikan Rasul kepadamu, Maka terimalah. dan apa yang dilarangnya bagimu, Maka tinggalkanlah. dan bertakwalah kepada Allah. Sesungguhnya Allah Amat keras hukumannya".

Ayat ini menjelaskan tentang hukum fai' secara terperinci. Ia memberikan penjelasan tentang sebab pembagian itu, dan meletakkan kaidah dalam sistem ekonomi dan sosial dalam masyarakat muslim.

Pada masa Rasul SAW harta fai' dibagi menjadi dua puluh lima bagian. Dua puluh bagian menjadi milik Rasul SAW. Beliau salurkan sesuai kebijaksanaan beliau, baik untuk diri dan keluarga yang beliau tanggung maupun selain mereka. Sedang lima bagian sisanya dibagikan sebagaimana pembagian ghanimah yang disebut dalam QS. al-Anfaal/8:41. Setelah Rasul SAW wafat, maka apa yang menjadi hak Rasul-menurut pandangan Imam Syafi'idibagikan kepada mujahidin yang bertugas membela negara, dan menurut pendapat yang lain, disalurkan untuk masyarakat umum berdasarkan prioritas kepentingan dan kebutuhannya. Adapun bagian Rasul dari ghanimah maka ulama sepakat bahwa ia dibagikan untuk kepentingan kaum muslimin (Shihab, 2002).

Imam Ahmad mengatakan, telah menceritakan kepada kami Sufyan, dari Amr dan Ma'mar, dari az-Zuhri, dari Malik Ibnu Aus Ibnu al-Hasan, dari Umar ra yang mengatakan bahwa dahulu harta Bani Nadhir termasuk harta fai' yang diberikan oleh Allah kepada Rasul-Nya, yaitu harta yang dihasilkan oleh kaum muslim tanpa menyerahkan seekor kuda pun dan juga tanpa menyerahkan seekor unta pun untuk menghasilkannya. Maka harta $f a i$ ' itu secara bulat untuk Rasulullah SAW, dan tersebutlah bahwa beliau SAW membelanjakan sebagian darinya untuk nafkah pertahun keluarganya. Kemudian pada kesempatan yang lain Umar ra mengatakan untuk keperluas hidup pertahun keluarganya. Sedangkan sisanya beliau belanjakan untuk keperluan 
peralatan dan senjata di jalan Allah SWT (Ibnu Katsir, 1874).

Sistem ekonomi islam merupakan sistem ekonomi yang terlahir dari sistem sosial islami yang diharapkan dapat memberikan solusi terhadap berbagai permasalahan yang ada (Manan, 1997), dengan kebijakan-kebijakan yang berpihak kepada kemashlahatan dan menciptkan keadilan dalam ekonomi umat. Begitu pula kebijakan distribusi dalam Sistem Ekonomi Islam menjunjung tinggi nilai keadilan, sehingga pada konsep distribusi landasan penting yang dijadikan pegangan yakni agar kekayaan tidak tertupuk hanya pada satu kelompok saja, sebagaimana tertuang dalam Q.S. al-Hasyr (59) ayat 7 , yang mengatakan:

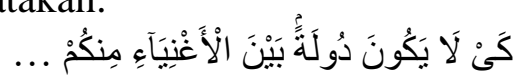

Artinya: "Supaya harta itu jangan hanya beredar diantara golongan kaya diantara kamu".

Secara etimologi, kata al-dulah dan aldaulah adalah lafazh sinonim, berakar kata dengan huruf-huruf dal-waw-lam. Al-daulah merupakan suatu ism (kata benda) yang zatnya terus berputar, sedangkan al-dulah adalah mashdar. Kata ad-daulah dalam surah al-Hasyr ayat 7 menunjukkan makna distribusi harta dan terkait dengan petunjuk Allah swt. bagaimana seharusnya harta kekayaan itu dikelola agar pemerataan terwujud di masyarakat. Kekayaan itu harus dibagi-bagikan kepada seluruh kelompok masyarakat dan bahwa harta kekayaan itu tidak boleh menjadi suatu komoditas yang peredarannya terbatas di antara orang-orang kaya saja. Kalimat dulatan baina agniya dimaksudkan sebagai milkan mutadawalan bainahum khassah (harta yang tersirkulasi khusus dikalangan mereka, maksudnya orang-orang kaya). Aldaulah adalah harta yang berputar di kalangan manusia dan beredar dari tangan ke tangan (Machluf, 1956).

Menurut Ibnu Katsir ayat ini bermakna bahwa pembagian harta $f a^{\prime} i$ yang sudah ditentukan memberikan gambaran kepada kita supaya distribusi harta tidak terletak pada tangan orang-orang kaya saja. Keberadaan harta pada tangan segelintir orang membuat ketidak-adilan dan ketimpangan distribusi yang mengakibatkan harta-harta tersebut tidak akan sampai kepada tangan orang-orang miskin (Ibnu Katsir, 1874). Menurut M. Quraish Shihab, ayat tersebut bermaksud untuk mnegaskan bahwa harta benda hendaknya jangan hanya menjadi milik dan kekuasaan sekelompok manusia. Akan tetapi harta benda harus beredar di masyarakat sehingga dapat dinikmati oleh semua anggota masyarakat dengan tetap mengakui hak kepemilikan dan melarang monopoli, karena sejak awal Islam menetapkan bahwa harta memiliki fungsi sosial (Shihab, 2002).

Bedasarkan ayat di atas, Ekonomi Islam tidak membenarkan penumpukan kekayaan hanya pada orang-orang tertentu. Bahkan, menggariskan prinsip keadilan dan persaudaraan (kasih saying) pada konsep distribusinya. Tidak membenarkan pengelolaan kekayaan hanya pada golongan atau kelompok orang tertentu namun tersebar ke seluruh masyarakat. Sebaliknya Islam pun tidak memaksa semua individu diletakkan pada tingkat ekonomi yang sama. Kebijakan distribusi yang diajarkan Islam sangat berkaitan dengan harta agar tidak menumpuk pada golongan terentu di masyarakat. Serta mendorong terciptanya keadilan distribusi, sehingga pemerintah dituntut untuk tidak berpihak pada satu kelompok atau golongan tertentu, agar proses distribusi dapat berjalan dengan adil. Hal ini dapat dipastikan dengan adanya kepastian sistem (ekonomi, hukum dan sosial) yang menjamin agar harta dapat tersebar luas di masyarakat (Rahman, 1995).

\subsection{Prinsip Distribusi Dalam Ekonomi Islam}

Kapitalisme tumbuh dan berkembang dari Inggris pada abad ke18, kemudian menyebar ke Eropa Barat dan Amerika Utara sebagai akibat dari perlawanan terhadap ajaran gereja yang pada akhirnya aliran ini merambah ke segala bidang termasuk bidang ekonomi. Dasar filosofis pemikiran ekonomi Kapitalis bersumber dari tulisan Adam Smith pada tahun 1776 dalam bukunya yang berjudul An Inquiry into the Nature and Causes of the Wealth of Nations. Pada dasarnya isi buku tersebut sarat dengan 
pemikiran-pemikiran tingkah laku ekonomi masyarakat. Dari dasar filosofi tersebut kemudian menjadi sistem ekonomi dan pada akhirnya mengakar menjadi ideologi yang mencerminkan suatu gaya hidup (way of life).

Landasan atau sistem nilai (value based) yang membentuk kapitalisme adalah sekulerisme dan materialisme, yang mana sekulerisme berusaha untuk memisakan ilmu pengetahuan dari agama dan bahkan mengabaikan dimensi normatif atau moral yang berdampak kepada hilangnya kesakralan kolektif (yang diperankan oleh agama) yang dapat digunakan untuk menjamin penerimaan keputusan ekonomi sosial. Sedangkan paham materialisme cendrung mendorong orang untuk memiliki pemahaman yang parsial tentang kehidupan dengan menganggap materi adalah segalahnya baginya (Anto, 2003).

Berkaitan dengan masalah distribusi, sistem kapitalisme menggunakan asas bahwa penyelesaian kemiskinan dan kekurangan dalam suatu negara dengan cara meningkatkan produksi dalam negeri dan memberikan kebebasan bagi penduduk untuk mengambil hasil produksi (kekayaan) sebanyak yang mereka produksi untuk negara. Dengan terpecahkannya kemiskinan dalam negeri, maka terpecah pula masalah kemiskinan individu sebab perhatian mereka pada produksi yang dapat memecah masalah kemiskinan pada mereka. Maka solusi yang terbaik untuk menyelesaikan permasalahan masyarakat adalah dengan meningkatkan produksi (Al-Maliki, 2001). Dengan demikian ekonomi hanya difokuskan pada penyediaan alat yang memuaskan kebutuhan masyarakat secara makro dengan cara menaikkan tingkat produksi dan meningkatkan pendapatan nasional (national income), sebab dengan banyaknya pendapatan nasional maka seketika itu terjadilah pendistribusian pendapatan dengan cara membertikan kebebasan memiliki dan kebebasan berusaha bagi semua individu masyarakat sehingga setiap individu dibiarkan bebas memperoleh kekayaan sejumlah yang dia mampu sesuai dengan faktorfaktor produksi yang dimilikinya dan memberikan kekayaannya kepada para ahli waris secara mutlak apabila mereka meninggal dunia. Asas distribusi yang diterapkan oleh sistem kapitalis ini pada akhirnya berdampak pada realita bahwa yang menjadi penguasa sebenarnya adalah para kapitalis (pemilik modal dan konglomerat), oleh karena itu hal yang wajar kalau kebijakankebijakan yang dikeluarkan oleh pemerintah selalu berpihak kepada para pemilik modal atau konglomerat dan selalu mengorbankan kepentingan rakyat sehingga terjadilah ketimpangan (ketidakadilan) pendistribusian pendapatan dan kakayaan.

Berbeda dengan ilmu ekonomi kapitalis, ilmu ekonomi Islam merupakan ilmu pengetahuan sosial yang mempelajari masalah-masalah ekonomi rakyat yang diilhami oleh nilai-nilai Islam. Dr. Muhammad bin Abdullah al-Arabi mendefinisikan ekonomi islam sebagai kumpulan prinsip-prinsip umum tentang ekonomi yang kita ambil dari al-qur'an, sunnah dan pondasi ekonomi yang kita bangun atas dasar pokokpokok itu dengan mempertimbangkan kondisi lingkungan dan waktu (At-Tariqi, 2004).

Ilmu ekonomi islam berkembang secara bertahap sebagai suatu bidang ilmu interdisipliner yang menjadi bahan kajian para fuqaha, mufassir, sosiolog dan politikus, diantaranya Abu Yusuf, Yahya bin Umar, Ibnu Khaldun dan lainnya. Konsep ekonomi para cendikiawan muslim tersebut berakar pada hukum islam yang bersumber dari al-qur'an dan hadits sehingga ia sebagai hasil interpretasi dari berbagai ajaran islam yang bersifat abadi dan universal, mengandung sejumlah perintah serta mendorong umatnya untuk mempergunakan kekuatan akal pikirannya (Karim, 2004).

Islam memandang pemahaman bahwa materi adalah segalanya bagi kehidupan sebagaimana menurut kaum kapitalisme adalah merupakan pemahaman yang salah, sebab manusia selain memiliki dimensi material juga memiliki dimensi non material (spiritual). Dalam realitanya tampak sekali bahwa paham materialisme membawa kehidupan manusia kepada kekayaan, kesenangan dan kenikmatan fisik belaka dengan mengabaikan dimensi non materi. 
Dalam ekonomi yang berbasis islam kedua dimensi tersebut (material dan non material) tercover didalamnya sebagaimana tercermin dari nilai dasar (value based) yang dimilikinya, yaitu ketuhidan, keseimbangan, kebebasan kehendak dan betanggung jawab (menurut syed Nawab Heidar Naqvy). Ketauhidan berfungsi untuk membedakan sang khaliq dan makhluknya yang diikuti dengan penyerahan tanpa syarat oleh setiap makhluk terhadap kehendak-Nya serta memberikan suatu perspektif yang pasti yang menjamin proses pencarian kebenaran oleh manusia yang pasti tercapai sepanjang menggunakan petunjuk Allah. Keseimbangan merupakan dimensi horisontal dari islam yang dalam perspektif yang lebih praktis meliputi keseimbangan jasmani-ruhani, material-non material, individu dan social. Sedangkan yang dimaksud dengan kebebasan kehendak disini adalah kebebasan yang dibingkai dengan tauhid, artinya manusia bebas tidak sebebas-bebasnya tetapi terikat dengan batasan-batasan yang diberikan oleh Allah. Dan tanggung jawab merupakan konsekuensi logis dari adanya kebebasan yang tidak hanya mencakup seluruh perbuatan di dunia dan akhirat saja tetapi juga terhadap lingkungan di sekitarnya (Anto, 2003).

Sistem ekonomi yang berbasis Islam menghandaki bahwa dalam hal pendistribusian harus berdasarkan dua sendi, yaitu sendi kebebasan dan keadilan kepemilikan (Qardhawi, 2001). Kebebasan disini adalah kebebasan dalam bertindak yang di bingkai oleh nilai-nilai agama dan keadilan tidak seperti pemahaman kaum kapitalis yang menyatakannya sebagai tindakan membebaskan manusia untuk berbuat dan bertindak tanpa campur tangan pihak mana pun, tetapi sebagai keseimbangan antara individu dengan unsur materi dan spiritual yang dimilikinya, keseimbangan antara individu dan masyarakat serta antara suatu masyarakat dengan masyarakat lainnya. Keberadilan dalam pendistribusian ini tercermin dari larangan dalam al-Qur'an agar supaya harta kekayaan tidak diperbolehkan menjadi barang dagangan yang hanya beredar diantara orang-orang kaya saja, akan tetapi diharapkan dapat memberi kontribusi kepada kesejahteraan masyarakat sebagai suatu keseluruhan (59:7) (Ahmad, 1998).

\subsection{Konsep Kesejahteraan Ekonomi Masya- rakat}

Kegiatan ekonomi telah menjadi sarana pencapaian kesejahteraan atau kemakmuran. Pada dasarnya semua lembaga keuangan memiliki tujuan yang sama yaitu meningkatkan kesejahteraan baik kesejahteraan untuk anggota atau kepada masyarakat luas. Namun ada pula yang tujuannya corebussines tanpa mempertimbangkan kesejahteraan masyarakat umum. Koperasi dalam perjalanannya sudah banyak memberikan andil dan kontribusi kepada masyarakat secara umum, terlebih kepada lembaga dan anggota dari sebuah koperasi. Peran koperasi itu sendiri tidak lepas dari manajemen dan pengelolaan yang baik.

Sebagaimana tujuan dari lembaga keuangan pada umumnya demi mewujudkan kesejahteraan bersama, maka sebenarnya kita berhadapan dengan konsep kesejahteraan. Konsep kesejahteraan dalam Islam dikenal dengan al-Falah, Hayatun al-Tayyibah, dan mashlahah al-ibad. Konsep tersebut merupakan cita-cita luhur dari ekonomi dan konsep Islam secara umum. Ketika berbicara tentang al-Falah dan Hayatun alTayyibah, maka kita berhadapan dengan rumusan M. Umer Chapra dan Al-Ghazali. Dalam bukunya Islamand The Islamic Challenge $\mathrm{M}$. Umer Chapra menjelaskan bahwa setiap individu pelaku ekonomi sudah pasti didominasi dengan pandangan maupun asumsinya mengenai alam, dan hakikat kehidupan manusia di dunia. Chapra mengibaratkan pandangan dunia sebagai pondasi bagi sebuah bangunan yang memainkan peranan yang sangat penting dan sangat menentukan. Sehingga strategi dari suatu sistem yang merupakan hasil logis dari pandangan hidup, selayaknya selaras dengan sasaran yang dipilih agar tujuan dapat dicapai dengan efektif (Chapra, 2000).

Chapra juga menjelaskan dalam buku ini mengenai aktualisasi konsep falah dan hayatan thoyyibatan yang merupakan inti dari tantangan 
ekonomi bagi negara-negara muslim. Sebab kedua konsep ini berasal dari Islam, diajarkan Islam dan hendaknya pula diterapkan dalam kehidupan muslim untuk mewujudkan kebahagiaan dunia-akhirat. Hal ini menuntut peningkatan moral, persaudaraan dan keadilan sosioekonomi, dengan pemanfaatan sumber-sumber daya yang langka untuk mengentaskan kemiskinan, memenuhi kebutuhan dan meminimalkan kesenjangan pendapatan dan kekayaan.

Dalam perspektif ide atau gagasan, ternyata konsep kesejahteraan banyak mengadopsi pada paham kapitalisme dan sosialisme. Paham ini telah terbukti membawa banyak kegagalan dalam mengantarkan pembangunan untuk mencapai kesejahteraan masyarakatnya. Oleh karena itu, muncullah sebuah alternatif konsep kesejahteraan yang mengacu pada nilai-nilai ajaran syariah Islam. Pada saat krisis ekonomi moneter melanda dunia, lembaga-lembaga ekonomi di negara-negara berkembang yang menerapkan mekanisme syariah terbukti dapat bertahan dan bahkan disebagiannya mampu untuk dapat tumbuh dan berkembang. Sehingga berawal dari keberhasilannya ini mulailah banyak dikaji tentang konsep kesejahteraan yang berlandaskan pada ekonomi syariah Islam (Hamidi, 2003).

Sementara itu, kesejahteraan menurut alGhazali adalah tercapainya kemaslahatan. Kemaslahatan sendiri merupakan terpeliharanya tujuan syara' (Maqasidal-Syari'ah). Manusia tidak dapat merasakan kebahagiaan dan kedamaian batin melainkan setelah tercapainya kesejahteraan yang sebenarnya dari seluruh umat manusia di dunia melalui pemenuhan kebutuhankebutuhan ruhani dan materi. Untuk mencapai tujuan syara' agar dapat terealisasinya kemaslahatan, Al-Ghazali menjabarkan tentang sumber-sumber kesejahteraan, yakni: terpeliharanya agama, jiwa, akal, keturunan dan harta (Rohman, 2010)

Aktualisasi konsep kesejahteraan tidak lepas dari peran dari para pelaku ekonomi. Di samping itu pula, peran masyarakat juga berkewajiban untuk merealisasikan kesejahteraan. Pemerintah dan masyarakat harus bergerak bersama untuk mencapai kesejahteraan umat. Kesejahteraan material dan spiritual merupakan tujuan yang ingin dicapai dalam proses pembangunan. Hal ini menunjukkan bahwa keberhasilan pembangunan haruslah dicapai tidak saja dalam aspek material, tetapi juga dalam aspek spiritual. Ketika sebuah proses pembangunan hanya diarahkan untuk mencapai keberhasilan material maka bisa dipastikan kesejahteraan masyarakat yang diinginkan tidak akan bisa tercapai. Masyarakat akan merasakan kehidupan yang hampa dan tanpa makna meskipun semua fasilitas tersedia.

Kesejahteraan oleh sebagian masyarakat selalu dikaitkan dengan konsep kualitas hidup. Konsep kualitas hidup merupakan gambaran tentang keadaan kehidupan yang baik. World Health Organization mengartikan kualitas hidup sebagai sebuah persepsi individu terhadap kehidupannya di masyarakat dalam konteks budaya dan sistem nilai yang ada yang terkait dengan tujuan, harapan, standar, dan juga perhatian terhadap kehidupan. Konsep ini memberikan makna yang lebih luas karena dipengaruhi oleh kondisi fisik individu, psikologis, tingkat kemandirian, dan hubungan sosial individu dengan lingkungannya (Fahrudin, 2012).

\subsection{Konsep Pengelolaan Koperasi Pesantren Untuk Kesejahteraan Ekonomi Masya- rakat}

Koperasi bertujuan meningkatkan kesejahteraan Anggota pada khususnya dan masyarakat pada umumnya, sekaligus sebagai bagian yang tidak terpisahkan dari tatanan perekonomian nasional yang demokratis dan berkeadilan (Pasal 4 UU No. 17 Tahun 2012).

Dari tujuan di atas, kalau kita melihat dari segi syariah dapat disimpulkan bahwa konsep pengelolaan kopersi pesantren untuk kesejahteraan ekonomi masyarakat harus memenuhi empat poin penting.

Pertama, mensejahterakan ekonomi Anggota/Masyarakat. Koperasi secara etimologi berasal dari kata "cooperation" dari bahasa inggris yang berarti kerjasama. Secra umum yang dimaksud dengan koperasi adalah suatu badan usaha bersama yang bergerak dalam 
bidang perekonomian, beranggotakan mereka yang berekonomi lemah yang bergabung secara sukarela dan atas dasar persamaan hak, berkewajiban melakukan sesuatu usaha yang bertujuan untuk memenuhi kebutuhan para anggotanya (Kertasaputra, 2001).

Pemenuhan kebutuhan para anggota/masyarakat tercermin dalam pembagian harta $f a$ ' $i$ yang telah digariskan peruntukannya oleh Allah SWT, dalam surat al-Hasyr ayat 7 yang mengatakan:

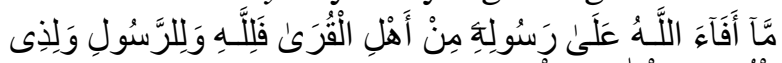

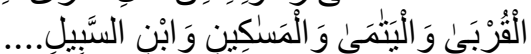

Artinya: “Apa saja harta rampasan (fai') yang diberikan Allah kepada RasulNya (dari harta benda) yang berasal dari penduduk kotakota Maka adalah untuk Allah, untuk rasul, kaum kerabat, anak-anak yatim, orang-orang miskin dan orang-orang yang dalam perjalanan...".

Peruntukan yang hanya tidak diberikan kepada Rasulullah memberikan gambaran bahwa harta yang dikelola tidak boleh hanya digunakan untuk kesenangan diri sendiri saja tetapi penggunaannya harus lebih luas yaitu harta bisa mensejahterakan anggota/masyarakat. Sebagaimana yang telah dicontohkan oleh Rasulullah saw, dalam penggunaan harta $f a^{\prime} i$ ini, beliau membelanjakan untuk keperluan anggota keluarganya, dibagikan kepada masyarakat yang berhak, dan sisanya digunakan untuk berbelanja perlengkapan perang (Ibnu Katsir, 1874).

Dalam Islam konsep mensejahterakan anggota/masyarakat juga sama dengan tolong menolong (ta'awun) dalam pemenuhan kebutuhan. Dalam surat At-Taubah Ayat 71 Allah berfirman:

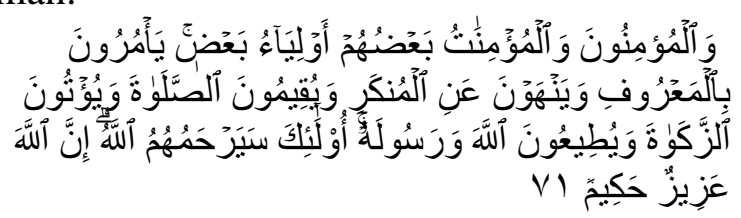

Artinya: "Dan orang-orang yang beriman, lelaki dan perempuan, sebahagian mereka (adalah) menjadi penolong bagi sebahagian yang lain. Mereka menyuruh (mengerjakan) yang ma'ruf, mencegah dari yang munkar, mendirikan shalat, menunaikan zakat dan mereka taat pada Allah dan Rasul-Nya. Mereka itu akan diberi rahmat oleh Allah; sesungguhnya Allah Maha Perkasa lagi Maha Bijaksana”.

Islam juga mendorong penganutnya berjuang untuk mendapatkan materi/harta dengan berbagai cara, asalkan mengikuti rambu-rambu yang telah ditetapkan.

Kedua, Keadilan Distribusi Pendapatan. Menurut Muhammad Hatta sebagai peletak dasar koperasi, keadilan distribusi pendapatan bermakna supaya tiap-tiap orang dalam masyarakat diperlakukan secara sama oleh Negara dalam segala rupa dan bebas dari tindakan kezaliman (Swasono \& Ridjal, 1992). Jadi konsep keadilan yang dimaksud Hatta menuntut kesamaan di depan hukum. Negara tidak boleh membedabedakan antara orang-seorang dengan lainnya. Negara harus memperlakukan mereka secara sama, termasuk dlaam bidang ekonomi, baik produksi, distribusi maupun konsumsi.

Bagaimana konsep keadilan yang hendak diperjuangkan Hatta tersebut? Keadilan yang harus ditegakkan itu kata Hatta bukanlah sembarang keadilan, tetapi adalah keadilan ilahi. Keadilan ilahi ini menurut Hatta baru dapat dilaksanakan apabila tercapai perdamaian dalam masyarakat, damai dalam perasaan manusia, antara dia dengan sekitarnya, damai antara manusia dan manusia, damai antara bangsa dengan bangsa. Inilah gambaran masyarakat Islam yang harus dilaksanakan dan inilah tugas kita (Hatta, 1985). Dari pernyataan ini tampak bahwa untuk tegaknya keadilan diperlukan syarat, berupa kedamaian. Ini artinya keadilan tidak akan bisa tegak kalau didalamnya masih ada praktik-praktik penjajahan dan atau eksploitatif serta hal-hal yang membawa kepada pelanggaran hak-hak orang lain.

Menurut Quraish Shihab, prinsip dalam keadilan distribusi pendapatan adalah keseimbangan. Prinsip keseimbangan mengantar kepada pencegahan segala bentuk monopoli dan pemusatan kekuatan ekonomi pada satu tangan atau satu kelompok. Atas dasar ini pula ALQuran menolak dengan amat tegas daur sempit 
yang menjadikan kekayaan hanya berkisar pada orang-orang atau kelompok tertentu.

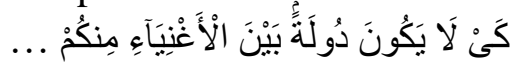

Artinya: "supaya harta itu jangan beredar di antara orang-orang Kaya saja di antara kamu."

Dari sini juga datang larangan penimbunan dan pemborosan. Hal ini tercermin ada ayat 34 surat Al-Taubah yang memberikan ancaman sedemikian keras kepada para penimbun.

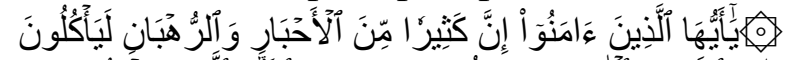

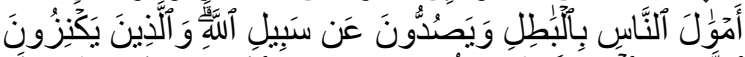

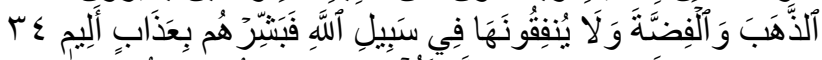

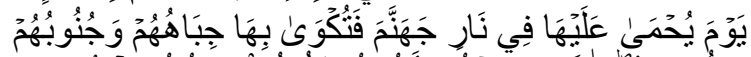

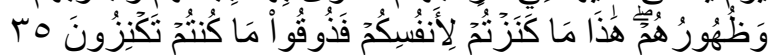

Artinya: "Hai orang-orang yang beriman, sesungguhnya sebahagian besar dari orangorang alim Yahudi dan rahib-rahib Nasrani benar-benar memakan harta orang dengan jalan batil dan mereka menghalang-halangi (manusia) dari jalan Allah. Dan orang-orang yang menyimpan emas dan perak dan tidak menafkahkannya pada jalan Allah, maka beritahukanlah kepada mereka, (bahwa mereka akan mendapat) siksa yang pedih. pada hari dipanaskan emas perak itu dalam neraka jahannam, lalu dibakar dengannya dahi mereka, lambung dan punggung mereka (lalu dikatakan) kepada mereka: "Inilah harta bendamu yang kamu simpan untuk dirimu sendiri, maka rasakanlah sekarang (akibat dari) apa yang kamu simpan itu" (Shihab, 2007).

Kesenjangan pendapatan dan kekayaan alam yang ada dalam masyarakat berlawanan dengan semangat serta komitmen Islam terhadap persaudaraan dan keadilan sosial-ekonomi. Kesenjangan harus diatasi dengan menggunakan caracara yang ditekankan Islam. Diantaranya adalah dengan cara-cara berikut ini:

1. Menghapuskan monopoli kecuali oleh pemerintah untuk bidang-bidang tertentu;

2. Menjamin hak dan kesempatan semua pihak untuk aktif dalam proses ekonomi, baik produksi, distribusi, sirkulasi, maupun konsumsi;

3. Menjamin basic needs fulfillment (pemenuhan kebutuhan dasar) setiap anggota masyarakat;

4. Melaksanakan amanah at-takaful al-ijtima'i atau social economic security insurance di mana yang mampu menanggung dan membantu yang tidak mampu (Antonio, 2001).

Dengan cara-cara ini, standar kehidupan setiap individu akan lebih terjamin, karena dalam konsep keadilan Islam dalam distribusi pendapatan dan kekayaan serta konsep keadilan ekonomi menghendaki setiap individu mendapatkan imbalan sesuai dengan amal dan karyanya. Ketidaksamaan pendapatan dimungkinkan dalam Islam karena kontribusi masing-masing orang kepada masyarakat berbeda-beda.

Ketiga, Keadilan dan Persaudaraan Menyeluruh. Dalam pasal 33 UUD 1945 menyatakan bahwa "perekonomian disusun sebagai usaha bersama berdasar asas kekeluargaan. Cabangcabang produksi yang penting bagi Negara dan yang menguasai hajat hidup orang banyak dikuasai oleh Negara. Bumi dan air dan kekayaan alam yang terkandung di dalamnya dikuasai oleh Negara dan dipergunakan untuk sebesar-besar kemakmuran rakyat".

Asas kekeluargaan dalam islam bermakna ukhuwah. Konsep ukhuwah pertama kali diperkenalkan oleh Nabi Muhammad saw. ketika beliau menginjakkan kaki di Madinah. Mulailah Nabi mempersaudarakan Muhajirin dan Anshar. Ini penting, bahkan teramat penting untuk menata dan mengelola suatu masyarakat. Persaudaraan yang dijalin atas dasar hubungan perjuangan dan harta lebih kuat efeknya dibandingkan hubungan nasab. Dengan jalan ini Nabi berhasil mengatasi krisis keuangan kaum Muhajirin yang datang ke Madinah tanpa membawa apapun selain pakaian yang mereka kenakan (Abazhah, 2014). Sejak itu, kaum Anshar belomba-lomba membantu saudarasaudara mereka kaum Muhajirin. Ditunjukkannya kepada kaum imigran ini perhatian dan sikap mendahulukan mereka.

Konsep ukhuwah islamiyah seperti di atas, dijelaskan dalam surat al-Hasyr ayat 9, ketika Allah memuji sifat kekeluargaan kaum Anshar terhadap kaum Muhajirin. 


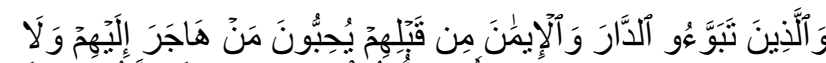

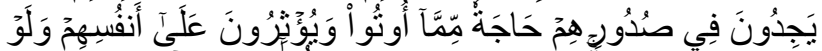

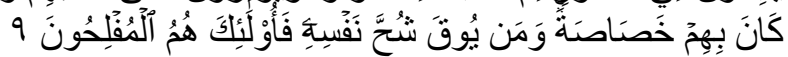
Artinya: "Dan orang-orang yang telah menempati kota Madinah dan telah beriman (Anshor) sebelum (kedatangan) mereka (Muhajirin), mereka (Anshor) 'mencintai' orang yang berhijrah kepada mereka (Muhajirin). Dan mereka (Anshor) tiada menaruh keinginan dalam hati mereka terhadap apa-apa yang diberikan kepada mereka (Muhajirin); dan mereka mengutamakan (orang-orang Muhajirin), atas diri mereka sendiri, sekalipun mereka dalam kesusahan. Dan siapa yang dipelihara dari kekikiran dirinya, mereka itulah orang orang yang beruntun".

Islam bertujuan untuk membentuk masyarakat dengan tatanan sosial yang solid dan dilindungi oleh rasa keadilan.. Dalam tatanan itu, setiap individu diikat oleh tali persaudaraan dan kasih sayang bagai satu keluarga. Sebuah persaudaraan yang universal dan tak diikat batas geografis. Dalam hal ini Allah berfirman dalam Surat Al-Maidah ayat 8:

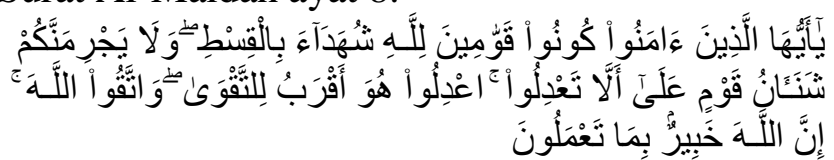

Artinya; "Hai orang-orang yang beriman hendaklah kamu Jadi orang-orang yang selalu menegakkan (kebenaran) karena Allah, menjadi saksi dengan adil. dan janganlah sekali-kali kebencianmu terhadap sesuatu kaum, mendorong kamu untuk Berlaku tidak adil. Berlaku adillah, karena adil itu lebih dekat kepada takwa. dan bertakwalah kepada Allah, Sesungguhnya Allah Maha mengetahui apa yang kamu kerjakan."

Keadilan dalam Islam memiliki dua implykasi, yaitu sebagai berikut:

1. Keadilan Sosial, Islam menganggap umat manusia sebagai satu keluarga. Karenanya semua anggota keluarga ini mempunyai derajat yang sama di hadapan Allah. Hukum Allah tidak membedakan yang kaya dan yang miskin, demikian juga tidak membedakan ras. Secara sosial nilai yang membedakan satu dengan yang lainnya adalah ketakwaan, ketulusan hati, kemampuan dan pelayanannya pada manusia.

2. Keadilan Ekonomi, Konsep persaudaraan dan perlakuan yang sama bagi setiap individu dalam masyarakat dan dihadapan hukum harus diimbangi oleh keadilan ekonomi. Tanpa pengimbangan tersebut, keadilan sosial akan kehilangan makna.

Keempat, Kebebasan individu dalam Konteks Kesejahteraan Sosial. Pilar yang paling penting dalam keyakinan seorang muslim adalah kepercayaan bahwa manusia diciptakan oleh Allah SWT. ia tidak tunduk kepada siapa pun kecuali kepada Allah (ar-Ra'd: 36 dan Luqman: 32). Ini merupakan dasar bagi Piagam Kemerdekaan Islam dari segala bentuk perbudakan. Menyangkut hal ini, Al-Quran dengan tegas menyatakan bahwa tujuan utama dari misi kenabian Muhammad saw, adalah melepaskan manusia dari beban dan rantai yang membelenggunya (al-A'raaf: 157).

Konsep islam amat jelas yaitu Manusia dilahirkan merdeka. Karenanya, tidak ada seorang pun yang berhak mencabut kemerdekaan tersebut dan membuat kehidupan manusia menjadi terikat. Dalam konsep ini, setiap individu berhak menggunakan kemerdekaannya sepanjang kemerdekaannya tetap berada dalam kerangka aturan islami. Dengan kata lain, sepanjang kebebasan tersebut dapat dipertanggungjawabkan secara sosial maupun di hadapan Allah.

Islam mengakui pandangan universal bahwa kebebasan individu bersinggungan atau bahkan dibatasi oleh kebebasan individu orang lain. Menyangkut masalah hak individu dalam kaitannya dengan masyarakat, para sarjana muslim sepakat pada prinsip-prinsip berikut ini:

1. Kepentingan masyarakat yang lebih luas harus didahulukan dari kepentingan individu.

2. Melepaskan kesulitan harus diprioritaskan dibanding memberi manfaat meskipun keduanya sama-sama merupakan tujuan syariah.

3. Kerugian yang lebih besar tidak dapat diterima untuk menghilangkan yang lebih kecil. Manfaat yang lebih besar tidak dapat dikorbankan untuk manfaat yang lebih kecil. Sebaliknya, bahaya yang lebih kecil harus 
dapat diterima/diambil untuk menghindarkan bahaya yang lebih besar, sedangkan manfaat yang lebih kecil dapat dikorbankan untuk mendapatkan manfaat yang lebih besar (Antonio, 2001).

\section{Kesimpulan}

Distribusi pendapatan yang adil merupakan salah satu kunci meningkatnya kesejahteraan ekonomi masyarakat. Monopoli Sumber Daya dan keberadaan harta pada tangan segelintir orang membuat ketidak-adilan dan ketimpangan distribusi yang mengakibatkan harta-harta tersebut tidak akan sampai kepada tangan orangorang miskin. Surat al-Hasyr ayat 7 mengajarkan bagaimana seharusnya proses distribusi ini berjalan dengan baik, dengan menerapkan prinsip-prinsip pokok, yang antara lain adalah, mensejahterakan ekonomi Anggota/Masyarakat, Keadilan Distribusi Pendapatan, Keadilan dan Persaudaraan Menyeluruh, Kebebasan individu dalam Konteks Kesejahteraan Sosial. Aktualisasi konsep kesejahteraan ini tidak hanya merupakan tugas para pelaku ekonomi saja. Di samping itu pula, masyarakat juga berkewajiban untuk merealisasikan kesejahteraan ekonomi mereka. Institusi koperasi pesantren yang bersentuhan langsung dengan masyarakat sudah seharusnya bisa menjadi ujung tombak dalam upaya peningkatan kesejahteraan ekonomi masyarakat.

\section{Ucapan Terimakasih}

Penulis enulis mengucapkan terima kasih sebesarbesarnya kepada Kedua orang tua kami, Dr. Prayitno Basuki, MA., Diswandi, Ph.D, Seluruh dosen dan staf pengajar Magister Ilmu Ekonomi, Universitas Mataram yang telah membantu dan memberikan ilmunya kepada penulis. Serata Sahabat seperjuangan, terima kasih atas sharing ilmu yang bermanfaat kepada penulis.

\section{Daftar Pustaka}

Abazhah, N. (2014). Fi Madinah al-Rasul, Terj. K.H. Asy'ari Khatib. Jakarta: Penerbit Zaman.
Ahmad, Z. (1998). Al-Qur'an: Kemiskinan dan Pemerataan Pendapatan. Yogyakarta: Dana Bhakti Prima Yasa.

Al-Maliki, A. (2001). Politik Ekonomi Islam, Terj. Ibnu Sholah, Bangil:Al-Izzah

Anto, H. (2003). Pengantar Ekonomika Mikro Islami. Yogyakarta: Ekonisia.

Antonio, S. (2001). Bank Syariah: Dari Teori ke Praktik. Jakarta: Gema Insani.

At-Tariqi, A. A. H. (2004). Ekonomi Islam (Prinsif, Dasar dan Tujuan), Terj. M. Irfan Syofwani. Yogyakarta: Magistra Insania Press.

Chapra, M. U. (2000). Islam dan Tantangan Ekonomi. Jakarta : Gema Insani Press.

Fahrudin, A. (2012). Pengantar Kesejahteraan Sosial. Bandung: Refika Aditama.

Gumilar Rusliwa Somantri. (2005). Memahami Metode Kualitatif. Jurnal Makara, Sosial Humaniora. 9(2), 57-65.

Hamidi, M. L. (2003). Jejak-Jejak Ekonomi Syariah. Jakarta: Senayan Abadi Publising.

Hatta, H. (1985). Kumpulan Pidato III. Jakarta: Inti Idayu Press.

Ibnu Katsir, I. (1874). Tafsir Al-Quran Al-Adzim. Lebanon, Dar el-Fikr.

Ibnu Khaldun. (2011). Mukaddimah, terj. Abdul al-Rahman. Jakarta: Pustaka al-Kausar.

Izhar. (2016). Mengidentifikasi Cara Berpikir Deduktif Dan Induktif Dalam Teks Bacaan Melalui Pengetahuan Koteks Dan Referensi Pragmatik. Jurnal Pesona. 2,(1), 63-73.

Karim, A. A. (2004). Sejarah Pemikiran Ekonomi Islam. Jakarta: Rajawali Pers.

Kertasaputra, G. (2001). Koperasi Indonesia yang Berdasarkan Pancasila dan UUD 1945, Cet ke-5. Jakarta: Rineka Cipta.

Machluf, H. M. (1956). Kalimat Al-Qur"ean. Tafsir wa bayan. Cairo: Dar al-Fikr.

Madjid, N. (Ed.). (1984). Khazanah Intelektual Islam. Bandung: Bulan Bintang.

Manan, M.A. (1997). Teori dan Praktik Ekonomi Islam, ter. M. Nastangin. Yogyakarta: Dana Bhakti Wakaf. 
Jurnal Ilmiah Ekonomi Islam, 4(02), 2018, 102

Muhadjir, N. (1996). Metodologi Penelitian Kualitatif. Edisi Ke-3. Rake Sarasin. Yogyakarta.

Qardhawi, Y. (2001). Norma dan Etika Ekonomi Islam, Terj. Zainal Arifin, Lc dan Dra. Dahlia Husin. Jakarta: Gema Insani Press.

Rahman, A. (1995). Doktrin Ekonomi Islam, jilid 1, Ter. Soeroyo, Nastangin. Yogyakarta: Dana Bakti Wakaf.

Rohman, A. (2010). Ekonomi Al-Ghazali, Menelusuri Konsep Ekonomi Islam dalam Ihya' Ulum al-Din. Surabaya: Bina Ilmu.

Shihab, M. Q. (2002). Tafsir al-Mishbah: Pesan, Kesan dan Keserasian Al-Quran,Vol. 14. Jakarta: Lentera Hati.
Shihab, M. Q. (2007). Wawasan Al-Quran: Tafsir Tematik atas Pelbagai Persoalan Umat. Bandung: Mizan Pustaka.

Swasono, S. E. (2007). Indonesia is not for sale: sistem ekonomi nasional untuk sebesarbesar kemakmuran rakyat: demokrasi ekonomi-ekonomi kelembagaan, economic democracy-institutional economics: catatan akhir tahun. Badan Perencanaan Pembangunan Nasional.

Swasono, S. E., \& Ridjal, F. (1992). Mohammad Hatta, Demokrasi Kita, Bebas Aktif, Ekonomi Masa Depan. Jakarta: UI Press.

UU No. 17 Tahun 2012 Tentang Perkoperasian 